\title{
Fatty acids, vitamins and cholesterol content, and sensory properties of cheese made with milk from sheep fed rapeseed oilcake
}

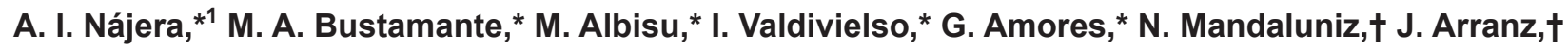 \\ L. J. R. Barron, ${ }^{*}$ and M. de Renobales* \\ *Lactiker Research Group, Faculty of Pharmacy, University of the Basque Country (UPV/EHU), Paseo de la Universidad 7, 01006 Vitoria-Gasteiz, \\ Spain \\ †Neiker-Tecnalia, PO Box 46, 01080 Vitoria-Gasteiz, Spain
}

\begin{abstract}
The aim of the present study was to evaluate the influence of rapeseed oilcake used for feeding sheep on the content of fatty acids (FA), tocopherols, retinoids, and cholesterol of milk and cheese, and on the sensory properties of cheese. Indoor animal feeding (in winter) is the highest cost of production for cheesemakers, and the inclusion of locally produced rapeseed oilcake in the concentrate feed formulation can reduce the cost of cheese production, as long as the quality of the cheese is not altered. The experiment was carried out in March (mid lactation) with 72 Latxa sheep from an experimental farm located in the Basque Country (northern Spain). Two homogeneous groups of animals $(\mathrm{n}=36)$ were set to receive each a different diet based on commercial or rapeseed concentrate, respectively, and forage (Festuca hay). Animal production parameters were individually recorded for each feeding group, whereas bulk milk from each group was used for cheesemaking trials. The rapeseed concentrate had higher amounts of unsaturated FA (mainly C18:1 cis isomers, C18:2 cis-9,cis-12 and C18:3 cis-9,cis-12,cis-15) and tocopherols than the commercial concentrate. The inclusion of rapeseed oilcake in the diet of dairy sheep did not compromise animal production parameters or milk gross composition. Bulk milk and cheese from sheep fed rapeseed concentrate showed higher content of unsaturated FA and tocopherols than those from sheep fed commercial concentrate. No differences were observed in the content of retinoid in milk and cheese between feeding groups, whereas the cholesterol content was slightly lower in cheese made with milk from sheep fed rapeseed concentrate. Thus, milk and cheese from sheep fed rapeseed concentrate had a healthier lipid profile. In addition, the inclusion of rapeseed oilcake in the diet
\end{abstract}

Received January 13, 2017.

Accepted May 26, 2017.

${ }^{1}$ Corresponding author: anaisabel.najera@ehu.eus of sheep did not change the typical sensory attributes of Protected Denomination of Origin Idiazabal cheese. Therefore, rapeseed concentrate could be a good local resource for feeding sheep to improve the nutritional quality of dairy products and to provide higher returns to farms.

Key words: rapeseed oilcake, sheep milk and cheese, fatty acid, vitamin

\section{INTRODUCTION}

Currently, the high cost of commercial feed prepared mainly from imported soy protein is one of the main problems for smallholder sheep livestock in northern Spain. The demand of the sector for local resources that can substitute soy protein is continuously increasing in order to improve the profitability of dairy farms. At the same time, animal feeding is one of the main factors that can modify the nutritional quality of milk, particularly its lipid profile linked to fatty acid (FA) composition and other minor compounds, such as tocopherols, retinoids, and cholesterol.

Linseed, soybeans, safflower, sunflower, and rapeseed are commonly used as lipid supplements to enhance the content of CLA and UFA in milk and cheese (Nudda et al., 2014). Although little is known about the effect of these lipid supplements on animal cholesterol metabolism, it has been reported that dietary supplementation of rapeseed oil significantly reduced the cholesterol content of cow milk (Altenhofer et al., 2014).

Few studies have focused on changes in the content of tocopherols, retinoids, and carotenoids in milk due to animal feeding, or on the transfer of these compounds from feeds to milk and cheese (Lucas et al., 2008; VargasBello-Pérez et al., 2013). Previous studies found that $\alpha$-tocopherol is the main isomer component of vitamin $\mathrm{E}$ in milk, and reported higher content in sheep than in cow and goat milk (Revilla et al., 2014). Retinol and xanthophylls have been detected in low concentrations in sheep and goat milk, but not $\beta$-carotene (Martin et al., 2004), because this compound is fully converted to 
retinol in sheep and goat intestine (Raynal-Ljutovac et al., 2008).

Regarding the effect of management practices on the variability of lipid composition of milk and cheese, an interesting study conducted by Lucas et al. (2008) reported that the nature of the basic fodder ration mostly affected the content of retinol, $\alpha$-tocopherol, and xanthophylls of goat milk and cheese. However, the FA composition was mainly affected by the composition of the concentrate and the lactation stage of the herd.

In the Basque Country of northern Spain, Latxa sheep milk production is mostly used to make Protected Denomination of Origin (PDO) Idiazabal cheese. Annual cheese production is around 1,000 t, and about half of it is produced by sheepherders with milk from their own flocks. Indoor animal feeding (in winter) represents the highest cost of production for cheesemakers, and the inclusion of locally produced rapeseed oilcake in the concentrate feed formulation can reduce the cost of cheese production, as long as the quality of the cheese is not altered. Previous studies reported that oilcakes can replace soya in the formulation of concentrates for sheep feeding, and that the use of oilcakes increased the concentration of nutritionally interesting FA in milk (Amores et al., 2014). However, it is necessary to study the effect of oilcakes on the nutritional and sensory quality of the final cheese produced. Thus, the aim of the present study was to assess the changes in the content of FA, tocopherols, retinoids, and cholesterol, and in the sensory properties of Idiazabal PDO cheese made with milk from rapeseed oilcake fed sheep.

\section{MATERIALS AND METHODS}

\section{Animals, Feeds, and Experimental Design}

The experimental design consisted of 2 different parts. The first was conducted with 72 Latxa sheep of the experimental flock of NEIKER-Tecnalia (Arkaute, Spain), in accordance with the European Council (1986)
Directive 86/609/ECC. At the start of the experiment, the experimental flock was divided in 2 homogeneous groups of animals (36 sheep per group) according to the month of lactation $(1 / 1.5 \mathrm{mo})$, daily milk production (DMP; $1.9 \pm 0.6 / 1.8 \pm 0.5 \mathrm{~L} /$ sheep per day), live weight $(61.0 \pm 7.0 / 59.0 \pm 9.0 \mathrm{~kg})$, and BCS $(2.4 \pm$ $0.5 / 2.5 \pm 0.5$ points). Average age of the sheep was 4.0 $\pm 1.5 \mathrm{yr}$ in both groups. One of the 2 groups was fed a standard diet based on commercial concentrate and forage (Festuca hay). Soya and cereals were the main protein and energy sources in the commercial concentrate. The other group of animals received a concentrate formulated with rapeseed oilcake along with Festuca hay. This rapeseed concentrate was formulated with $225 \mathrm{~g}$ of rapeseed oilcake per kilogram of DM instead of the soya in the commercial concentrate. Oilcake was the by-product of the cold extraction of oil from locally produced rapeseed seeds. Table 1 shows the gross nutritional composition of rapeseed oilcake, commercial and rapeseed concentrates, and forage. Animals were milked twice a day at 0730 and $1830 \mathrm{~h}$. For both feeding groups, the concentrate was divided into 2 halves and provided during milking, whereas the forage was offered ad libitum after each milking. The daily intake per feeding group was calculated by weighing the feed supply and the refusal in each of the milkings, and it was considered that the animals ate ad libitum when the refusal was less than 10\% (by weight).

The experiment consisted of an unreplicated design of feeding groups as experimental units. The experiment was carried out in March (mid lactation) for a total of $3 \mathrm{wk}$, allowing the first week as adaptation time. Sheep were weighed (live weight) once a week and, simultaneously, BCS was monitored using a 5-point scale, with 1 for a thin animal and 5 for an obese animal (Russel et al., 1969). Average DMP was determined for individual animals from the 2 daily milkings.

The second part of the experiment consisted of cheesemaking trials made with bulk milk from each feeding group (commercial and rapeseed groups). In this case,

Table 1. Gross nutritional composition of rapeseed oilcake, commercial and rapeseed concentrates, and forage (Festuca hay)

\begin{tabular}{lcccc}
\hline Item & $\begin{array}{c}\text { Rapeseed } \\
\text { oilcake }\end{array}$ & $\begin{array}{c}\text { Commercial } \\
\text { concentrate }\end{array}$ & $\begin{array}{c}\text { Rapeseed } \\
\text { concentrate }\end{array}$ & Festuca hay \\
\hline DM (\%) & 89.27 & 88.79 & 89.53 & 85.9 \\
CP (\%) & 24.76 & 14.58 & 14.85 & 12.9 \\
Crude fat (\%) & 20.08 & 3.89 & 6.56 & 1.80 \\
Crude fiber (\%) & $<5$ & 6.93 & 7.21 & 30.9 \\
ADF (\%) & & & & 55.7 \\
NDF (\%) & 1.1 & 1.03 & 1.08 & 0.80 \\
Energy (UFL $\left.{ }^{1}\right)$ & & & & \\
\hline
\end{tabular}

${ }^{1} \mathrm{UFL}=$ unité fourragère lait. 
the cheesemaking trial was the experimental unit. Cheesemaking trials for each concentrate group were done once a week, during the last $2 \mathrm{wk}$ of the experiment, in the same dairy (Larrea, Álava, Spain), with around 150 $\mathrm{L}$ of bulk raw milk per vat. The bulk milk was collected and refrigerated at $4^{\circ} \mathrm{C}$ before cheesemaking. The trials were carried out as specified by Idiazabal PDO Regulatory Council rules (Ministerio de Agricultura, Pesca y Alimentación, 1993). Commercial bovine rennet (Marshall Powder, Rhône-Poulenc Texel, Dangé-SaintRomain, France) and homofermentative starter culture (Lactococcus lactis ssp. lactis and Lactococcus lactis ssp. cremoris, EZAL, Rhône-Poulenc Texel) were used. Cheeses $(\sim 1.1-1.3 \mathrm{~kg})$ were ripened at 8 to $10^{\circ} \mathrm{C}$ and 80 to $85 \%$ relative humidity for up to $90 \mathrm{~d}$.

\section{Feed, Milk, and Cheese Sampling}

Triplicate samples (250 g) of commercial and rapeseed concentrates and Festuca hay were taken for feed gross composition analysis. Bulk milk samples (1.5 L) were taken 3 times a week during the last 2 wk of the experiment ( $\mathrm{n}=6$ for each feeding group), and 2 cheeses were sampled from each vat $(\mathrm{n}=4$ for each feeding group). Aliquots of milk samples were stored in 50-mL containers at $-80^{\circ} \mathrm{C}$ until analysis. Cheeses were cut in 200-g sections, vacuum-packed, and frozen at $-80^{\circ} \mathrm{C}$. In addition, another whole cheese from each vat was taken for sensory analysis. Milk and cheese DM was determined as described in IDF $(1962,2004)$. All milk and cheese samples were stored in darkness to ensure a better preservation of lipid compounds, mainly of UFA and vitamins, against oxidation.

\section{Analytical Procedures}

$\boldsymbol{F A}$ Analysis. Fat from feed and cheese samples (0.4 $\mathrm{g}$ each) was extracted as previously described (Folch et al., 1957), whereas that from milk samples (1.6 g) was extracted as described by Secchiari et al. (2003). A 2-step methylation was carried out as previously described (Christie, 1982; Kramer et al., 1997). Fatty acid methyl esters were separated on a CP-Sil 88 fused capillary column $(100 \mathrm{~m} \times 0.25 \mathrm{~mm}$ i.d.; $0.39 \mu \mathrm{m}$ film thickness; Agilent Technologies, Palo Alto, CA) installed in a 7890A gas chromatograph (Agilent Technologies) coupled to a flame ionization detector, as previously described (Buccioni et al., 2010). Quantification was done using $n$-heneicosanoic acid (C21:0) as internal standard added to the sample at the time of extraction. The FAME were identified by comparing the retention time of sample chromatographic peaks with that of commercial standards. Supelco 37 component FAME mix ( $>98 \%$ purity) was purchased from Sigma-Aldrich (Madrid, Spain). Individual FA standards (>90\% purity; iso $\mathrm{C} 14$, anteiso $\mathrm{C} 14$, iso $\mathrm{C} 15$, anteiso $\mathrm{C} 15$, iso $\mathrm{C} 16$, iso $\mathrm{C} 17$, anteiso $\mathrm{C} 17, \mathrm{C} 18: 1$ cis-11, C18:1 trans-11, C18:2 trans-10,cis-12, C18:2 cis-9,trans-11, and C22:6 cis-4,cis-7,cis-10,cis-13,cis-16,cis-19) were purchased from Larodan (Malmö, Sweden); C21 (>99\% purity) was supplied by $\mathrm{Nu}-\mathrm{Chek}$ (Elysian, MN). Results were expressed as millimoles of FA per kilogram of DM of feed, milk, or cheese, because biochemical and chemical reactions and physiological effects occur on a molar rather than on a weight basis. In addition, molar units facilitated data comparison between different samples and a better understanding of the transfer of lipid compounds from milk to cheese.

Tocopherol, Carotenoid, Retinoid, and Cholesterol Analysis. Tocopherols and carotenoids were simultaneously extracted from feed samples as previously described using 1-step solid-liquid phase (Valdivielso et al., 2015a). Tocopherols, retinoids, and cholesterol were simultaneously extracted from milk and cheese samples using the procedures described by Valdivielso et al. (2015b). Tocopherols and retinoids extracted from the different samples were simultaneously separated by normal phase-HPLC on a Zorbax RX-SIL column (25 $\mathrm{cm} \times 4.6 \mathrm{~mm}$ i.d.; $5 \mu \mathrm{m}$ particle size; Agilent Technologies) installed in a 2695 Alliance separation module (Waters, Barcelona, Spain) coupled to a fluorescence detector (model 474, Waters), as described (Valdivielso et al., 2015a). Carotenoids extracted from feeds were separated by reversed phase-HPLC on a C30 YMC column $(25 \mathrm{~cm} \times 4.6 \mathrm{~mm}$ i.d.; $5 \mu \mathrm{m}$ particle size; Waters) installed in a 2695 Alliance separation module (Waters) coupled to photodiode array detector (model 996, Waters), as described (Valdivielso et al., 2015a). Cholesterol extracted from milk and cheese samples was simultaneously analyzed by normal phase-HPLC using a UV/VIS detector (model 2151, LKB, Bromma, Sweden) connected in series. Tocopherols, carotenoids, retinoids, and cholesterol were identified by comparing the retention time of sample chromatographic peaks with that of commercial standards. High-purity $(>90 \%)$ standards of $\alpha-, \beta-, \gamma-$, and $\delta$-tocopherol, $\alpha$-tocopherol acetate, $\alpha$ - and $\gamma$-tocotrienol, retinol, retinyl palmitate, $\beta$-carotene, and lutein ( $>75 \%$ purity) were purchased from Sigma-Aldrich. Antheraxanthin ( $>98 \%$ purity) was purchased from Danish Hydraulic Institute (Hoersholm, Denmark), and cholesterol (>95\% purity) from Panreac (Madrid, Spain). Quantification was based on external standard calibration. As mentioned for FA analysis, the results were expressed in molar units $(\mu \mathrm{mol} / \mathrm{kg}$ of DM of feed, milk, or cheese). All sample preparations were performed under yellow light 
at room temperature to ensure a better preservation of lipid compounds against oxidation.

Sensory Analysis. Sensory analysis of cheeses was carried out by the 7 trained members of the expert panel of the official control of Idiazabal cheese following the accredited method 472/L1020 (Pérez-Elortondo et al., 2007). Eight sensory parameters (cheese shape, rind, internal color, internal eyes, odor, texture, flavor, and persistence) were assessed on a 7-point discontinuous scale as previously described (Ojeda et al., 2015). Cheeses were kept at 4 to $6^{\circ} \mathrm{C}$ for up to 1 wk after sampling. Before sensory analysis, the cheeses were tempered at $17^{\circ} \mathrm{C}$ and rind-free coded samples were randomly presented to assessors together with other Idiazabal PDO commercial cheeses in each session. Four sessions in 2 consecutive weeks $(2$ sessions per week) were carried out by the panel, and 2 cheeses from different cheesemaking trials were assessed in each session.

Statistical Analysis. Four significant figures were used to express (mean \pm SD) the content of FA, tocopherols, carotenoids, retinoids, and cholesterol in feed, milk, and cheese samples. SPSS statistical package version 23.0 (IBM, Armonk, NY) was used for data treatment. The general linear model of ANOVA was used to determine the presence of absence of significant differences in animal production parameters, milk and cheese composition, and sensory attributes of cheese due to animal feeding. For animal production parameters, the following model was used:

$$
Y_{i j k l}=\mu+F_{i}+W_{j}+A_{k}+F \times W_{i j}+\varepsilon_{i j k l},
$$

whereas for bulk milk and cheese compositional and sensory variables, the following model was used:

$$
Y_{i j k}=\mu+F_{i}+W_{j}+F \times W_{i j}+\varepsilon_{i j k},
$$

where $Y_{i j k l}$ and $Y_{i j k}=$ dependent variables; $\mu=$ mean value (intercept); $F_{i}=$ animal feeding fixed effect; $W_{j}=$ week fixed effect; $A_{k}=$ individual animal random effect; and $\varepsilon_{i j k l}$ and $\varepsilon_{i j k}=$ random residual effects. Mean FA, tocopherol, and carotenoid composition of commercial and rapeseed concentrates were compared using Student's $t$-test. Significance level was set at $P \leq 0.05$.

\section{RESULTS AND DISCUSSION}

\section{Animal Production Parameters}

After the adaptation period, sheep in both feeding groups consumed around $36 \mathrm{~kg}$ of concentrate and $58 \mathrm{~kg}$ of forage per group and day. The forage-to- concentrate ratio of the diet for both feeding groups was constant (62:38) during the experiment, and no concentrate or forage refusal was observed throughout the trial. No differences $(P>0.05)$ were found at the end of the experiment for individual animal production parameters between the rapeseed- and the commercial concentrate-fed groups. Mean and standard deviation for live weight, BCS and average DMP were $61.60 \pm$ $1.10 \mathrm{~kg}, 2.47 \pm 0.06$ points, and $1.66 \pm 0.04 \mathrm{~L} /$ sheep per day, respectively. Therefore, replacement of soya by rapeseed oilcake in the commercial concentrate formulation did not compromise animal production parameters of dairy sheep.

\section{Feed Composition}

Table 1 shows the gross nutritional composition of feeds used for the 2 feeding groups. As observed, the percentage of crude fat $(\mathbf{C F})$ in rapeseed concentrate was around 1.7-fold higher than in commercial concentrate, but energy values for both concentrate formulations were very similar (1.03-1.08). Thus, the diets for both feeding groups were isoenergetic and isoproteic. In addition to the differences in the amount of fat, the FA composition also showed differences $(P \leq 0.05)$ between rapeseed and commercial concentrate formulations, in particular for UFA (Table 2). Rapeseed concentrate had 3.1-, 1.3-, and 4.2-fold higher concentrations of $\mathrm{C} 18: 1$ cis-9, C18:2 cis-9,cis-12, and C18:3 cis-9,cis12, cis-15, respectively, than commercial concentrate. Percentage of $\mathrm{CF}$ of forage (Festuca hay) was lower than that of concentrates, with C18:3 cis-9,cis-12,cis-15 as the major FA. Very few data have been reported in the literature about FA composition of forages used for animal feeding. Data reported in our study agree with those reported for Festuca species in fresh pasture (Valdivielso et al., 2016).

Tocopherol and carotenoid composition of feeds is shown in Table 3. Four tocopherols, 2 tocotrienols, and tocopherol acetate were identified. Rapeseed concentrate showed 3.4-fold higher concentration of total tocols than commercial concentrate. Particularly high were the amounts of $\gamma$-tocopherol and $\alpha$-tocopherol (free or as acetate) in rapeseed concentrate, whereas the most abundant tocopherol in Festuca hay was $\alpha$-tocopherol, the amount of which was lower than that reported for Festuca species in fresh pasture (Valdivielso et al., 2016). Carotenoids were only detected in the forage. Antheraxanthin, $\beta$-carotene, and lutein were found in Festuca hay, with lutein the most abundant (Table 3). As mentioned for $\alpha$-tocopherol, the carotenoid content of Festuca hay was lower than that reported for Festuca species in fresh pasture (Valdivielso et al., 2016). In 
this regard, losses of carotenoid content close to $80 \%$ between direct-cut silage and hay have been previously reported (Chauveau-Duriot et al., 2005).

\section{Bulk Milk and Cheese Composition}

No differences $(P>0.05)$ were found in DM, CF, and CP percentages in bulk milk and cheese between both feeding groups. Mean values of DM, CF, and CP in bulk milk were $10.42 \pm 0.12,6.18 \pm 0.14$, and $4.62 \pm$ 0.04 , respectively, whereas $63.58 \pm 1.07,38.86 \pm 1.74$, and $24.72 \pm 2.27$, were the mean values of $\mathrm{DM}, \mathrm{CF}$, and $\mathrm{CP}$ in cheese, respectively.

Table 4 shows the FA composition of bulk milk and cheese from commercial or rapeseed concentrate feeding groups. As previous studies reported, cheese FA profile was quite similar to that of milk (Valdivielso et al., 2015b). Main FA in bulk milk and cheese were C16, C18:1 cis-9, C14, C10, C18, C4, and C6. Rapeseed concentrate caused a significant reduction $(P \leq$ $0.05)$ in the concentration of FA with chain lengths between 6 and 17 carbon atoms (mostly SFA), and an increase in the amount of $\mathrm{C} 18$ and C18:1 isomers. Polyunsaturated FA with chain length longer than 18 carbon atoms were present, in general, in similar amounts in bulk milk and cheese from both feeding groups (Table 4). With the exception of iso C17, the content of odd- and branched-chain FA was lower in milk and cheese in the rapeseed than in the commercial concentrate-fed group. Other authors reported that unsaturated lipid supplements in the animal diet may decrease the content of odd- and branched-chain FA (Baumann et al., 2016; Conte et al., 2016), which originate by rumen microbiota. This decrease has been linked to a higher dietary concentration of PUFA, such as $\mathrm{C} 18: 2$ cis- 9 ,cis- 12 or $\mathrm{C} 18: 3$ cis- 9 ,cis-12,cis- 15 , which can be toxic for rumen bacteria, particularly for cellulolytic bacteria (Vlaeminck et al., 2006; Maia et al., 2007). As a consequence, the higher intake of these PUFA in the diet probably caused the lower content of odd- and branched-chain FA in the milk from feeding sheep rapeseed concentrate.

Bulk milk and cheese from the rapeseed concentrate group had around $6.10 \%$ and $8.59 \%$ higher amount $(P$

Table 2. Mean and SD of the concentration ( $\mathrm{mmol} / \mathrm{kg}$ of $\mathrm{DM})$ of fatty acids in commercial concentrate, rapeseed concentrate, and forage (Festuca hay)

\begin{tabular}{|c|c|c|c|}
\hline Fatty acid & $\begin{array}{l}\text { Commercial } \\
\text { concentrate }\end{array}$ & $\begin{array}{l}\text { Rapeseed } \\
\text { concentrate }\end{array}$ & Festuca hay \\
\hline$\overline{\mathrm{C} 4}$ & $0.2351 \pm 0.0521^{\mathrm{b}}$ & $0.3691 \pm 0.0261^{\mathrm{a}}$ & $0.1462 \pm 0.0312$ \\
\hline C6 & $0.1822 \pm 0.0242^{\mathrm{b}}$ & $0.6242 \pm 0.0632^{\mathrm{a}}$ & $0.0202 \pm 0.0202$ \\
\hline $\mathrm{C} 8$ & $\mathrm{ND}^{1}$ & $0.2273 \pm 0.0062$ & $0.0514 \pm 0.0042$ \\
\hline C9 & ND & $0.2414 \pm 0.0232$ & $0.0663 \pm 0.0083$ \\
\hline C10 & $0.2113 \pm 0.0642$ & $0.2511 \pm 0.0033$ & $0.9753 \pm 0.0743$ \\
\hline $\mathrm{C} 12$ & $0.0434 \pm 0.0223$ & $0.0672 \pm 0.0194$ & $0.2951 \pm 0.0064$ \\
\hline $\mathrm{C} 13$ & ND & ND & $0.0772 \pm 0.0072$ \\
\hline iso $\mathrm{C} 14$ & ND & ND & $0.4243 \pm 0.0303$ \\
\hline C14 & $0.1934 \pm 0.0224^{\mathrm{b}}$ & $0.3652 \pm 0.0322^{\mathrm{a}}$ & $0.2603 \pm 0.0101$ \\
\hline C15 & $0.0653 \pm 0.0152$ & $0.0743 \pm 0.0711$ & $0.0652 \pm 0.0182$ \\
\hline iso $\mathrm{C} 16$ & ND & ND & $2.135 \pm 0.0344$ \\
\hline $\mathrm{C} 16$ & $16.72 \pm 1.628^{\mathrm{b}}$ & $22.64 \pm 1.660^{\mathrm{a}}$ & $8.149 \pm 0.1183$ \\
\hline iso $\mathrm{C} 17$ & ND & $0.0181 \pm 0.0321$ & ND \\
\hline C16:1 cis-9 & $0.1542 \pm 0.0192^{\mathrm{b}}$ & $0.5972 \pm 0.0441^{\mathrm{a}}$ & $0.0902 \pm 0.0012$ \\
\hline $\mathrm{C} 17$ & $0.0671 \pm 0.0113^{\mathrm{b}}$ & $0.1072 \pm 0.0142^{\mathrm{a}}$ & $0.1102 \pm 0.0082$ \\
\hline $\mathrm{C} 18$ & $1.599 \pm 0.1903^{\mathrm{b}}$ & $4.042 \pm 0.3273^{\mathrm{a}}$ & $0.7643 \pm 0.0173$ \\
\hline $\mathrm{C} 18: 1$ cis -9 & $29.16 \pm 2.614^{\mathrm{b}}$ & $90.56 \pm 7.368^{\mathrm{a}}$ & $1.283 \pm 0.0983$ \\
\hline $\mathrm{C} 18: 1$ cis-11 & $1.262 \pm 0.1292^{\mathrm{b}}$ & $7.639 \pm 0.6262^{\mathrm{a}}$ & $0.1794 \pm 0.0434$ \\
\hline C18:2 cis- 9, cis-12 & $35.00 \pm 3.919^{\mathrm{b}}$ & $44.02 \pm 3.280^{\mathrm{a}}$ & $4.922 \pm 0.1381$ \\
\hline $\mathrm{C} 20$ & $0.2971 \pm 0.0452^{\mathrm{b}}$ & $0.9262 \pm 0.0982^{\mathrm{a}}$ & $0.2594 \pm 0.0242$ \\
\hline C20:1 cis -13 & $0.6142 \pm 0.0842^{\mathrm{b}}$ & $1.621 \pm 0.1372^{\mathrm{a}}$ & ND \\
\hline $\mathrm{C} 18: 3$ cis-9,cis-12,cis-15 & $1.832 \pm 0.2994^{\mathrm{b}}$ & $7.739 \pm 0.5952^{\mathrm{a}}$ & $13.14 \pm 0.1413$ \\
\hline C20:2 cis-11,cis-14 & $0.0713 \pm 0.0031^{\mathrm{b}}$ & $0.2892 \pm 0.0393^{\mathrm{a}}$ & ND \\
\hline $\mathrm{C} 22$ & $0.2043 \pm 0.0351^{\mathrm{b}}$ & $0.5511 \pm 0.0724^{\mathrm{a}}$ & $0.4052 \pm 0.0172$ \\
\hline $\mathrm{C} 22: 1$ & $0.1081 \pm 0.0142^{\mathrm{b}}$ & $0.2473 \pm 0.0194^{\mathrm{a}}$ & $0.0594 \pm 0.0144$ \\
\hline $\mathrm{C} 23$ & $0.0742 \pm 0.0063$ & $0.0862 \pm 0.0332$ & $0.1053 \pm 0.0124$ \\
\hline C20:5 cis-5,cis-8,cis-11,cis-14,cis-17 & $0.1262 \pm 0.0111^{\mathrm{b}}$ & $0.2614 \pm 0.0282^{\mathrm{a}}$ & $0.3781 \pm 0.0532$ \\
\hline C24:1 cis-15 & $0.3512 \pm 0.0212$ & $0.4154 \pm 0.0921$ & $0.1131 \pm 0.0093$ \\
\hline Total fatty acids & $88.52 \pm 9.104^{\mathrm{b}}$ & $183.7 \pm 14.44^{\mathrm{a}}$ & $36.32 \pm 4.178$ \\
\hline
\end{tabular}

${ }^{\mathrm{a}, \mathrm{b}}$ Means with different superscripts in the same row indicate statistically significant differences between commercial and rapeseed concentrate $(P \leq 0.05)$.

${ }^{1} \mathrm{ND}=$ not detected. 
RAPESEED OILCAKE: SHEEP MILK AND CHEESE

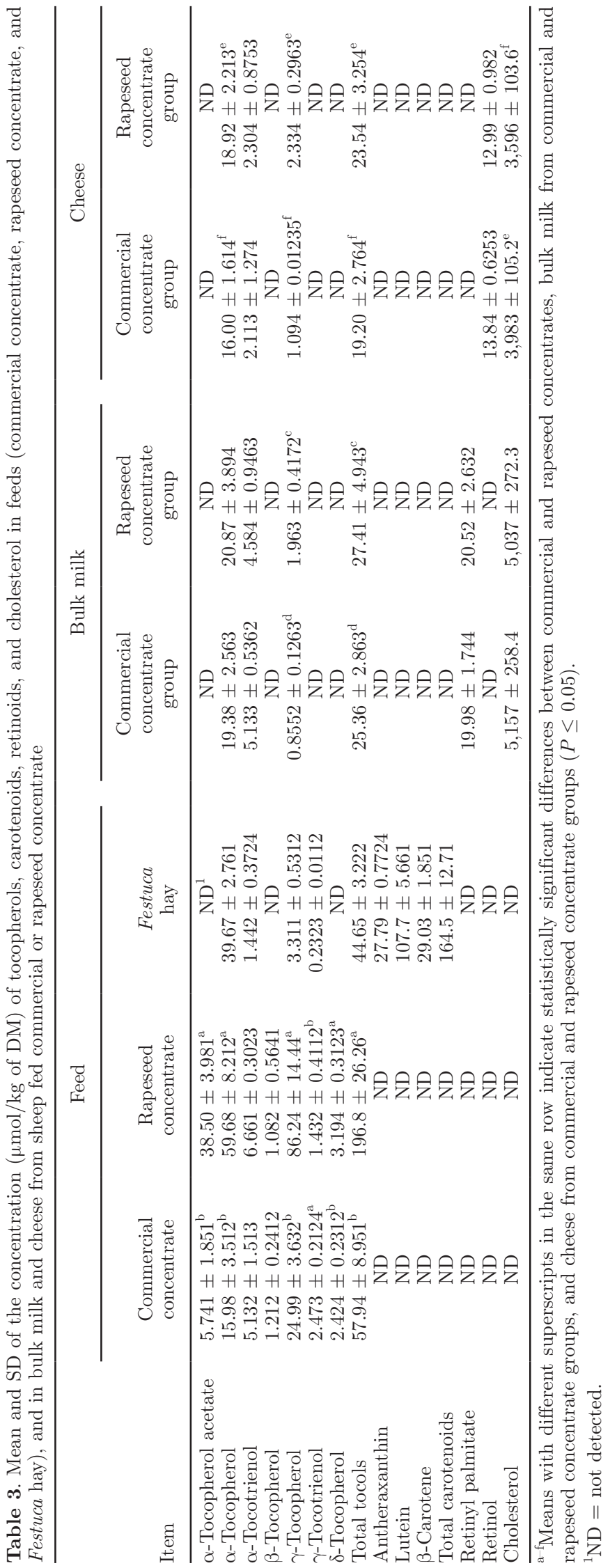


Table 4. Mean and SD of the concentration (mmol/kg of DM) of fatty acids in bulk milk and cheese from sheep fed commercial or rapeseed concentrate

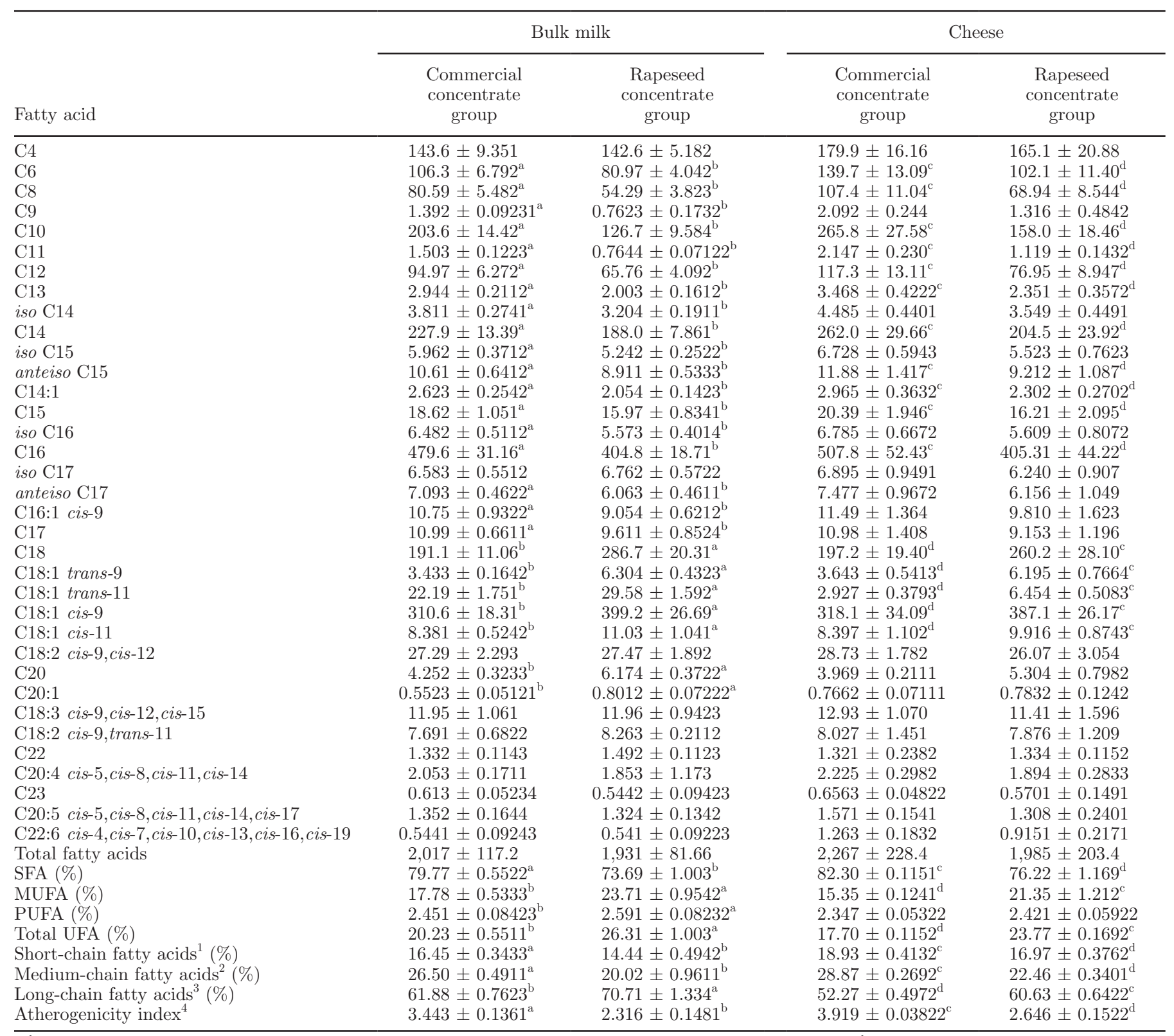

\footnotetext{
${ }^{\mathrm{a}-\mathrm{d}}$ Means with different superscripts in the same row indicate statistically significant differences between ${ }^{\mathrm{a}, \mathrm{b}}$ bulk milk from commercial and rapeseed concentrate groups and ${ }^{\mathrm{c}, \mathrm{d}}$ cheese from commercial and rapeseed concentrate groups $(P \leq 0.05)$.

${ }^{1}$ Short-chain fatty acids = chain length lower than C10.

${ }^{2}$ Medium-chain fatty acids = chain length from C10 to C14.

${ }^{3}$ Long-chain fatty acids $=$ chain length higher than C14.

${ }^{4}$ Atherogenicity index was calculated as follows: $[\mathrm{C} 12+4 \times(\mathrm{C} 14)+\mathrm{C} 16] / \mathrm{UFA}-[($ tMUFA - VA $)+(\mathrm{CLA}-\mathrm{RA})]$, where UFA was the total content of UFA, tMUFA was the total content of trans MUFA (C18:1), VA was vaccenic acid (C18:1 trans-11), CLA was the total content of conjugated linoleic acid isomers, and RA was rumenic acid (C18:2 cis-9,trans-11) (Valdivielso et al., 2015b).
}

$\leq 0.05$ ) of unsaturated and long-chain FA, respectively, than those from the commercial concentrate group. The higher total FA content found in rapeseed concentrate (Table 2) could result in a higher dietary intake and secretion of long-chain FA into milk fat (Chilliard et al., $2000)$. The atherogenic index significantly $(P \leq 0.05)$ decreased in the milk and cheese from the rapeseed concentrate group compared with the values obtained 
in commercial concentrate one (from 3.44 to 2.32 and 3.92 to 2.65 for bulk milk and cheese, respectively).

Fatty acid composition of milk and cheese revealed the presence of many UFA that were not present in concentrates and forage. This was the case of C18:1 trans-9 and trans-11 isomers, C18:2 cis-9,trans-11, C20:4 cis5,cis-8,cis-11,cis-14, and C22:6 cis-4,cis-7,cis-10,cis13, cis-16,cis-19 present in milk and cheese samples. As it has been reported, these FA are originated by microbial hydrogenation in the rumen and subsequent enzymatic desaturation of intermediate compounds in the mammary gland (Palmquist et al., 2005), mainly from C18:2 cis-9,cis-12 and C18:3 cis-9,cis- 12, cis- 15 , which were present in higher concentration in rapeseed than in commercial concentrate (Table 2). Furthermore, the higher content of C18:1 cis-9 in rapeseed concentrate (Table 2) resulted in higher content of this FA in bulk milk and cheese from rapeseed than from commercial concentrate group (Table 4). However, no differences $(P<0.05)$ were found in the content of $\mathrm{C} 18: 1$ cis11, C18:2 cis-9,cis-12, and C18:3 cis-9,cis-12,cis-15 of milk and cheese between the rapeseed and commercial concentrate groups despite the higher content of these UFA in rapeseed concentrate (Table 2), most likely due to the biohydrogenation process of UFA in the rumen.

Three tocols were identified in bulk milk and cheese samples, $\alpha$-tocopherol the most abundant (Table 3). Despite the higher amount of $\alpha$ - and $\gamma$-tocopherol in rapeseed concentrate, slight differences were observed in the content of both tocopherol isomers in milk and cheese between the rapeseed and commercial concentrate groups. On the other hand, total tocol content was lower in cheese than in bulk milk (around 24 and $14 \%$ lower for commercial and rapeseed concentrate groups, respectively). In this regard, losses in the content of vitamin E during the cheesemaking process was previously reported by other authors (Lucas et al., 2006; Valdivielso et al., 2016). No differences $(P>$ $0.05)$ were found in the total and individual content of retinoids in bulk milk and cheese between the rapeseed and commercial concentrate groups. Due to the saponification reaction used for extracting tocols, carotenoids, and retinoids in the cheese samples (Valdivielso et al., 2015b), retinol was the retinoid compound detected in cheese whereas retinyl palmitate was found in milk. As mentioned for tocols, the total content of retinoids was lower in cheese than in milk (around 31 and $37 \%$ lower in the commercial and rapeseed concentrate groups, respectively; Table 3). According to the literature, a high percentage of milk retinol can be lost during cheesemaking, probably due to its association with whey proteins such as $\alpha$-LA and $\beta$-LG (Lucas et al., 2006). The content of milk and cheese retinoids found in milk and cheese in the present study are in agreement with those previously reported (Valdivielso et al., 2015b, 2016).

Despite of the presence of carotenoids in the forage (Table 3), no carotenoids were detected in bulk milk and cheese from both animal feeding groups, most likely due to the active degradation of dietary carotenoids by rumen microorganisms (Martin et al., 2004; RaynalLjutovac et al., 2008). The cholesterol content of bulk milk from both feeding groups did not differ $(P>0.05)$, whereas a slight decrease $(P \leq 0.05)$ was observed in the cheese from the rapeseed concentrate group (Table 3 ). The cheese samples from both feeding groups had between 84 and $95 \mathrm{mg}$ of cholesterol/100 g of cheese, which is in accordance with previously reported values for other sheep cheese varieties (Marrone et al., 2014). Other authors reported that the supplementation of sheep diet with linseed oil decreased the cholesterol content of cheese (Gómez-Cortés et al., 2015).

\section{Sensory Analysis}

Sensory parameters of cheeses made with bulk milk from the commercial or rapeseed concentrate groups were similar $(P>0.05)$, with the exception of internal appearance (eyes), for which cheeses made with milk from the rapeseed concentrate group received higher scores (5.6 and 6.6 for commercial and rapeseed concentrate cheeses, respectively). Mean values for sensory parameters of cheeses from both feeding groups were $4.4 \pm 0.8$ for odor, $4.1 \pm 0.7$ for texture, $4.2 \pm 0.7$ for flavor, $4.3 \pm 0.8$ for persistence, $5.7 \pm 0.8$ for shape, 4.7 \pm 0.8 for rind, and $4.7 \pm 0.9$ points for internal color. These scores were in accordance to the PDO Idiazabal sensory requirements for product quality (MAGRAMA, 2014; Ojeda et al., 2015). Therefore, the inclusion of rapeseed oilcake in the diet of sheep did not change the typical sensory attributes of Idiazabal cheese. Other studies on bovine cheeses made with milk from cows fed different vegetable oils also reported minor effects on the sensory properties of cheese (Ryhänen et al., 2005; Vargas-Bello-Pérez et al., 2015).

\section{CONCLUSIONS}

Changes in lipid compounds of sheep milk and cheese due to rapeseed concentrate feeding caused a healthier lipid profile in dairy products as compared with commercial concentrate feeding. In addition, the inclusion of rapeseed oilcake in the diet of sheep did not change the typical sensory attributes of PDO Idiazabal cheese. Therefore, rapeseed concentrate could be a good local resource for feeding sheep to improve the nutritional 
quality of dairy products and to provide higher returns to farms.

\section{ACKNOWLEDGMENTS}

Financial support was provided by the Department of Education, Language Policy and Culture (IT76613; IT944-16), and the Department of Industry (SPEUN108 SAIOTEK) of the Basque Government.

\section{REFERENCES}

Altenhofer, C., M. Spornraft, H. Kienberger, M. Rychlik, J. Herrmann, H. H. D. Meyer, and E. Viturro. 2014. Effects of rapeseed and soybean oil dietary supplementation on bovine fat metabolism, fatty acid composition and cholesterol levels in milk. J. Dairy Res. 81:120-128. https://doi.org/10.1017/S002202991300071X.

Amores, G., M. Virto, A. I. Nájera, N. Mandaluniz, J. Arranz, M. A. Bustamante, I. Valdivielso, J. C. Ruiz de Gordoa, A. GarcíaRodríguez, L. J. R. Barron, and M. de Renobales. 2014. Rapeseed and sunflower oilcake as supplements for dairy sheep: Animal performance and milk fatty acid concentrations. J. Dairy Res. 81:410 416. https://doi.org/10.1017/S0022029914000521.

Baumann, E., P. Y. Chouinard, Y. Lebeuf, D. E. Rico, and R. Gervais 2016. Effect of lipid supplementation on milk odd-and branchedchain fatty acids in dairy cows. J. Dairy Sci. 99:6311-6323. https:// doi.org/10.3168/jds.2015-10746.

Buccioni, A., S. Rapaccini, M. Antongiovanni, S. Minieri, G. Conte, and M. Mele. 2010. Conjugated linoleic acid (CLA) and C18:1 isomers content in milk fat of sheep and their transfer to Pecorino Toscano D.O.P. cheese. Int. Dairy J. 20:190-194. https://doi. org/10.1016/j.idairyj.2009.10.001.

Chauveau-Duriot, B., D. Thomas, J. Portelli, and M. Doreau. 2005. Carotenoids content in forages: Variation during conservation. Rencontres Rech. Rumin. 12:117.

Chilliard, Y., A. Ferlay, R. M. Mansbridge, and M. Doreau. 2000. Ruminant milk fat lasticity: Nutritional control of saturated, polyunsaturated, trans and conjugated fatty acids. Ann. Zootech. 49:181-205.

Christie, W. W. 1982. A simple procedure for rapid transmethylation of glycerolipids and cholesteryl esters. J. Lipid Res. 23:1072-1075.

Conte, G., A. Serra, P. Cremonesi, S. Chessa, B. Castiglioni, A. Cappucci, E. Bulleri, and M. Mele. 2016. Investigating mutual relationship among milk fatty acids by multivariate factor analysis in dairy cows. Livest. Sci. 188:124-132. https://doi.org/10.1016/j. livsci.2016.04.018.

European Council. 1986. Council Directive 86/609/ECC on the approximation of laws, regulations and administrative provisions of the Member States regarding the protection of animals used for experimental and other scientific purposes. Accessed Jan. 10, 2017. http://eur-lex.europa.eu/legal-content/EN/ TXT/?uri=CELEX:31986L0609.

Folch, J., M. Lees, and G. H. S. Stanley. 1957. A simple method for the isolation and purification of total lipids from animal tissues. J. Biol. Chem. 226:497-509.

Gómez-Cortés, P., E. Viturro, M. Juárez, and M. A. de la Fuente. 2015. Alternative to decrease cholesterol in sheep milk cheeses. Food Chem. 188:325-327. https://doi.org/10.1016/j. foodchem.2015.05.012.

IDF. 1962. Dry matter and ash. IDF Standard No. 21. International Dairy Federation, Brussels, Belgium.

IDF. 2004. Cheese and processed cheese. Determination of the tota solids content. IDF Standard No. 4. International Dairy Federation, Brussels, Belgium.

Kramer, J. K. G., V. Fellner, M. E. R. Dugan, F. D. Sauer, M. M. Mossoba, and M. P. Yurawecz. 1997. Evaluating acid and base catalysts in the methylation of milk and rumen fatty acids with special emphasis on conjugated dienes and total trans fatty acids. Lipids 32:1219-1228. https://doi.org/10.1007/s11745-997-0156-3.

Lucas, A., C. Agabriel, B. Martin, A. Ferlay, I. Verdier-Metz, J. B. Coulon, and E. Rock. 2006. Relationships between the conditions of cow's milk production and the contents of components of nutritional interest in raw milk farmhouse cheese. Lait 86:177-202. https://doi.org/10.1051/lait:2005049.

Lucas, A., J. B. Coulon, C. Agabriel, Y. Chilliar, and E. Rock. 2008 Relationships between the conditions of goat's milk production and the contents of some components of nutritional interest in Rocamadour cheese. Small Rumin. Res. 74:91-106. https://doi. org/10.1016/j.smallrumres.2007.04.001.

MAGRAMA. 2014. Ministerio de Agricultura, Alimentación y Medio Ambiente. [Specifications. Protected Denomination of Origin (PDO) Idiazabal]. Accessed Jan. 10, 2017. http://www.magrama. gob.es/es/alimentacion/temas/calidad-agroalimentaria/pliego incluidas_modif_idi_v6-5-14_tcm7-326642_tcm7-309359.pdf.

Maia, M. R. G., L. C. Chaudhary, L. Figueres, and R. J. Wallace 2007. Metabolism of polyunsaturated fatty acids and their toxicity to the microflora of the rumen. Antonie van Leeuwenhoek 91:303-314. https://doi.org/10.1007/s10482-006-9118-2.

Marrone, M., A. Balestrieri, T. Pepe, L. Vollano, N. Murru, M. J D'Occhio, and A. Anastasio. 2014. Physicochemical composition, fatty acid profile and cholesterol content of "Pecorino Carmasciano" cheese, a traditional Italian dairy product. J. Food Compos. Anal. 36:85-89. https://doi.org/10.1016/j.jfca.2014.05.006.

Martin, B., V. Fedele, A. Ferlay, P. Grolier, D. Rock, D. Gruffat, and Y. Chilliard. 2004. Effects of grass-based diets on the content of micronutrients and fatty acids in bovine and caprine dairy products. Grassl. Sci. Eur. 9:876-886.

Ministerio de Agricultura, Pesca y Alimentación. 1993. Regulation of the Denomination of Origin Idiazabal and its Regulatory Council. Boletín Oficial del Estado 289:34591-34596.

Nudda, A., G. Battacone, O. Boaventura Neto, A. Cannas, A. H. Dias Francesconi, A. S. Atzori, and G. Pulina. 2014. Feeding strategies to design the fatty acid profile of sheep milk and cheese. Rev. Bras. Zootec. 43:445-456. https://doi.org/10.1590/S151635982014000800008

Ojeda, M., I. Etaio, M. P. Fernández Gil, M. Albisu, J. Salmerón, and F. J. Pérez-Elortondo. 2015. Sensory quality control of cheese: Going beyond the absence of defects. Food Contr. 51:371-380. https://doi.org/10.1016/j.foodcont.2014.11.034.

Palmquist, D. L., A. L. Lock, K. J. Shingfield, and D. E. Bauman. 2005. Biosynthesis of conjugated linoleic acid in ruminants and humans. Adv. Food Nutr. Res. 50:179-217. https://doi.org/10.1016/ S1043-4526(05)50006-8.

Pérez-Elortondo, F. J., M. Ojeda, M. Albisu, J. Salmerón, I. Etaio, and M. Molina. 2007. Food quality certification: An approach for the development of accredited sensory evaluation methods. Food Qual. Prefer. 18:425-439. https://doi.org/10.1016/j. foodqual.2006.05.002.

Raynal-Ljutovac, K., G. Lagriffoul, P. Paccard, I. Guillet, and Y. Chilliard. 2008. Composition of goat and sheep milk products: An update. Small Rumin. Res. 79:57-72. https://doi.org/10.1016/j. smallrumres.2008.07.009.

Revilla, I., I. Lobos-Ortega, A. Vivar-Quintana, M. I. González-Martín, J. M. Hernández-Hierro, and C. González-Pérez. 2014. Variations in the contents of vitamins $\mathrm{A}$ and $\mathrm{E}$ during the ripening of cheeses with different compositions. Czech J. Food Sci. 32:342-347.

Russel, A. J. F., J. M. Doney, and R. G. Gunn. 1969. Subjective assessment of body fat in live sheep. J. Agric. Sci. 72:451-454.

Ryhänen, E. L., K. Tallavaara, J. M. Griinari, S. Jaakkola, S. Mantere-Alhonen, and K. J. Shingfield. 2005. Production of conjugated linoleic acid enriched milk and dairy products from cows receiving grass silage supplemented with a cereal-based concentrate containing rapeseed oil. Int. Dairy J. 15:207-217. https://doi. org/10.1016/j.idairyj.2004.07.003.

Secchiari, P., M. Antongiovanni, M. Mele, A. Serra, A. Buccioni, G. Ferruzzi, F. Paoletti, and F. Petacchi. 2003. Effect of kind of dietary fat on the quality of milk fat from Italian Friesian cows. 
Livest. Prod. Sci. 83:43-52. https://doi.org/10.1016/S03016226(03)00043-5.

Valdivielso, I., M. A. Bustamante, A. Aldezabal, G. Amores, M. Virto, J. C. Ruiz de Gordoa, M. de Renobales, and L. J. R. Barron. 2016. Case study of a commercial sheep flock under extensive mountain grazing: Pasture derived lipid compounds in milk and cheese. Food Chem. 197:622-633. https://doi.org/10.1016/j. foodchem.2015.10.133.

Valdivielso, I., M. A. Bustamante, A. Buccioni, O. Franci, J. C. Ruiz de Gordoa, M. de Renobales, and L. J. R. Barron. 2015b. Commercial sheep flocks - fatty acid and fat-soluble antioxidant composition of milk and cheese related to changes in feeding management throughout lactation. J. Dairy Res. 82:334-343. https://doi. org/10.1017/S0022029915000369.

Valdivielso, I., M. A. Bustamante, J. C. Ruiz de Gordoa, A. I. Nájera, M. de Renobales, and L. J. R. Barron. 2015a. Simultaneous analysis of carotenoids and tocopherols in botanical species us- ing one step solid-liquid extraction followed by high performance liquid chromatography. Food Chem. 173:709-717. https://doi. org/10.1016/j.foodchem.2014.10.090.

Vargas-Bello-Pérez, E., K. Fehrmann-Cartes, G. Iñiguez-González, P. Toro-Mujica, and P. C. Garnswothy. 2015. Chemical composition, fatty acid composition, and sensory characteristics of Chanco cheese from dairy cows supplemented with soybean and hydrogenated vegetable oils. J. Dairy Sci. 98:111-117. https://doi. org/10.3168/jds.2014-8831.

Vargas-Bello-Pérez, E., E. E. Vera, E. Aguilar, R. Lira, I. Peña, and J. Fernández. 2013. Feeding olive cake to ewes improves fatty acid profile of milk and cheese. Anim. Feed Sci. Technol. 184:94-99. https://doi.org/10.1016/j.anifeedsci.2013.05.016.

Vlaeminck, B., V. Fievez, A. R. J. Cabrita, A. J. M. Fonseca, and R. J. Dewhurst. 2006. Factors affecting odd-and branched-chain fatty acids in milk: A review. Anim. Feed Sci. Technol. 131:389-417. https://doi.org/10.1016/j.anifeedsci.2006.06.017. 